\title{
Presenilin 1 and Cadherins: Stabilization of Cell-Cell Adhesion and Proteolysis-Dependent Regulation of Transcription
}

\author{
Loukia Parisiadou Angeliki Fassa Angeliki Fotinopoulou loanna Bethani \\ Spiros Efthimiopoulos \\ Division of Animal and Human Physiology, Department of Biology, University of Athens, Athens, Greece
}

\author{
Key Words \\ Alzheimer's disease - Amyloid precursor protein . \\ Presenilin · Cadherin
}

\begin{abstract}
Presenilin-1 (PS1) has gained intensive attention in relation to Alzheimer's disease, since it has been shown that PS1 mutations are linked to familial Alzheimer's disease (FAD), and that PS1 is a member of the high molecular weight complex of $\gamma$-secretase, which generates the carboxyl end of $\beta$-amyloid peptide ( $\gamma$-cleavage). A parallel line of evidence suggests that upon formation of cell-cell contacts, presenilin colocalizes with cadherins at the cell surface and stabilizes the cadherin-based adhesion complex. Under conditions stimulating cell-cell dissociation, cadherins are processed by a PS $1 / \gamma$-secretase activity, promoting disassembly of adherens junctions, and resulting in the increase of cytosolic $\beta$-catenin, which is an important regulator of the Wnt/Wingless signaling pathway. PS1 also controls the cleavage of a number of transmembrane proteins at the interface of their transmembrane and cytosolic domains ( $\varepsilon$-cleavage), producing intracellular fragments with a putative transcriptional role. Remarkably, cleavage of $\mathrm{N}$-cadherin by PS1 produces an intracellular fragment that downregulates CREB-mediated transcription, indicating a role of PS1 in gene expression. PS1 mutations associated with FAD abol-
\end{abstract}

\section{KARGER}

Fax +41613061234

E-Mail karger@karger.ch

www. karger.com
(C) 2004 S. Karger AG, Basel

1660-2854/04/0015-0184\$21.00/0

Accessible online at:

www. karger.com/ndd ish production of the $\mathrm{N}$-cadherin intracellular fragment and thus fail to suppress CREB-dependent transcription. These findings suggest an alternative explanation for $F A D$ that is separate from the widely accepted 'amyloid hypothesis': dysfunction in transcription regulatory mechanisms.

Copyright $@ 2004$ S. Karger AG, Basel

Alzheimer's disease (AD), originally described by Alois Alzheimer in 1907, is a neurodegenerative disorder resulting in dementia, characterized by progressive loss of cognitive abilities. The pathophysiology of AD is defined by a large number of fibrillar deposits called neuritic plaques, whose major proteinaceous component is $\beta$-amyloid peptide $(\mathrm{A} \beta)$, neurofibrillary tangles, oxidative neuronal damage and inflammatory cascades. The disease is inherited as a Mendelian trait in only $5 \%$ of all cases, and these are regarded as the familial form of $\mathrm{AD}$ (FAD) [for a review, see 1]. Mutations of three genes have been identified which are involved in the early-onset FAD: the amyloid precursor protein (APP) gene and the genes encoding the homologous presenilin (PS) proteins PS1 and PS2 [2]. Consistent with this idea, mutations in the APP and PS genes have been reported to be related with $\mathrm{AD}$ by altering the processing of APP [3-8]. The remaining cases of the disease are sporadic and affect individuals after the age of 65 , in contrast with the FAD forms that 
occur earlier. Thus, it is easy to appreciate that AD is a multifaceted disease, and both environmental and genetic factors are responsible for its development.

The major constituent of amyloid plaques deposited in brain of AD patients is a short 39- to 43-amino acid peptide called $\mathrm{A} \beta$. It is produced by the posttranslational proteolysis of a larger protein, the APP [9, 10]. APP gene locus was found on chromosome 21 and alternative exon splicing produces three major isoforms of 695,751 or 770 amino acids [9]. APP is a type I transmembrane glycoprotein that through the course of its life span is processed by different proteases called secretases [11]. The first proteolytic cleavage identified takes place 12 amino acids $\mathrm{NH}_{2}-$ terminal to the transmembrane domain of APP and is catalyzed by the enzyme $\alpha$-secretase [12]. Pharmacological studies reported that metalloprotease TACE (tumor necrosis factor- $\alpha$-converting enzyme) [13] and ADAM 10 [14] are related with the $\alpha$-secretase processing, which is considered nonamyloidogenic, as the enzyme cleaves within the $A \beta$ region of APP. In the alternative pathway, two distinct proteolytic enzymes, $\beta$-secretase and $\gamma$-secretase, generate the amino-terminus and the carboxyl-terminus of $A \beta$, respectively [1].

\section{Presenilin 1}

PS1 gained great attention in relation to $\mathrm{AD}$ when gene mapping in patients with an autosomal dominant form of early onset AD led to the identification of human PS gene in 1995 [15]. According to the most widely accepted topological model, PS1 includes 8 transmembrane domains with the $\mathrm{N}$ - and $\mathrm{C}$-domains as well as the large hydrophilic loop between transmembrane domain 6 and 7 being cytosolic $[16,17]$. The PS holoprotein undergoes constitutive endoproteolysis resulting in the production of a stable heterodimer composed of an N-terminal fragment and a C-terminal fragment (CTF) [18, 19]. A number of studies support the idea first described by Wolfe et al. [20] that PS seems to be the catalytic component of $\gamma$-secretase [2123]. However, the following observations show that the specific protein alone is not sufficient for protease activity, which is consistent with the notion that $\gamma$-secretase is a high-molecular-weight, multiprotein complex. Biochemical purification of the PS-containing high-molecularweight complex led to the identification of the second member of the complex called nicastrin after the Italian village Nicastro, where genetic studies of FAD were performed [24]. Genetic screens designed to modify a PSdeficient phenotype in Caenorhabditis elegans yielded two novel genes APH-1 (anterior pharynx-defective phenotyope) [25] and PEN-2 (PS enhancer) [26]. Coexpression of the four human proteins (PS1, Nct, Aph-1 and Pen-2) in cultured mammalian cells enhances $\gamma$-secretase activity [27-29]. Recent findings also suggest that these four proteins are sufficient to reconstitute the active $\gamma$ secretase complex in Saccharomyces cerevisiae that lacks endogenous $\gamma$-secretase activity [30]. There are at least two PS $1 / \gamma$-secretase-dependent cleavages namely the $\gamma$ cleavage and the $\varepsilon$-cleavage. The $\gamma$-cleavage takes place in the middle of the transmembrane domain of APP and other type I transmembrane proteins and is responsible for the generation of the C-terminus of $A \beta$ or $A \beta$-like peptides $[31,32]$. The $\varepsilon$-cleavage takes place close to the interface of the transmembrane and cytosolic domains of the proteins and is responsible for the release of their cytoplasmic domains to the cytosol [33-36].

\section{Cadherins}

$\mathrm{E}$ (epithelial)- and $\mathrm{N}$ (neuronal)-cadherin are the bestcharacterized of the classical cadherins that mediate cell adhesion, play a fundamental role in normal development and participate in the maintenance of proper cell-cell contacts. The cadherins are single pass transmembrane glycoproteins of about 700- to 750-amino acid residues that typically consist of five tandem repeated extracellular domains, a single membrane-spanning segment and a cytoplasmic region. The function of cadherins is $\mathrm{Ca}^{2+}$ dependent: removal of calcium abolishes adhesive activity and renders cadherins vulnerable to proteases. The large extracellular parts of cadherins of two opposing cells form calcium-dependent homophilic junctions, whereas a serine-rich region of the cytoplasmic domain has been shown to be associated with proteins termed catenins. Specifically, cadherins bind to $\beta$-catenin, which in turn associates with $\alpha$-catenin, and $\alpha$-actin, thus connecting the cadherin-catenin complex to the actin cytoskeleton, ensuring the integrity and stabilization of the adhesion.

\section{Interaction of PS1 with Cadherins}

Georgakopoulos et al. [37] presented data indicating that PS1 upon formation of cell-cell contact is recruited at sites of cell-cell adhesion, where it forms complexes with E-cadherin and $\beta$-catenin. Laser scanning confocal micrographs and immunogold electron microscopy of confluent MDCK cells showed a similar distribution of PS1 and 
E-cadherin/ $\beta$-catenin at sites of cell-cell contacts on the lateral plasma membrane. This concentration of PS1 at the plasma membrane has given a satisfactory justification of the processing of Notch1 and APP at the plasma membrane, a fact that was inconsistent with the previously reported intracellular site of PS1 [38, 39]. In cells lacking cell-cell contacts, PS1 is predominantly localized in the ER/Golgi apparatus. To further support the initial data indicating cell surface expression of PS1, they performed coimmunoprecipitation experiments that show a physical interaction of PS1 with components of the cadherin-based adherens junction (CAJs). More specifically, it has been shown that E-cadherin binds directly to PS1 and the specific binding is mediated by 340 - to 375 -amino acid residues of PS1/CTF and by amino acid residues 604-615 of E-cadherin, which are also required for the binding of protein p120 [40]. Continuous adjustment and regulation of cadherins allow cells to control the critical events of cell adhesion, embryogenesis and tissue remodeling. The molecular mechanism underlying the modulation of cadherins remains elusive. A number of studies argue that $\mathrm{p} 120$ is an important regulator of cadherin function [41-44]. Using wild-type and PS1 knockout cells it has been shown that PS1 overexpression decreased significantly p120/Ecadherin binding, and conversely increasing levels of p120 suppressed PS1/E-cadherin interaction [40]. These observations suggest that PS1 competes with p120 for binding to E-cadherin, implying a key role for PS1 in the regulation of the cadherin-associated system. Besides PS1 localization at cell-cell contacts of epithelial tissue, it has been observed that it forms complexes with cadherins in brain, suggesting a functional role of PS1 in synaptic adhesions [37]. Moreover, double labeling in immunocytochemistry experiments of SH-SY5Y cells showed colocalization of PS1 and N-cadherin at the cell-cell contact sites. The reported colocalization is significantly reduced in dominant negative mutated PS (D385A)-transfected cells, indicating that overexpression of the mutant PS1 causes disassembly of the N-cadherin/PS1 complex.

\section{WT PS1 but Not FAD Mutants Stabilizes the Cadherin-Based Junctions}

In order to address a possible functional role of PS1 at cell-cell adhesion, HEK 293 cells were stably transfected with wild-type PS1 and PS1 mutant (D257A) [37]. They reported a statistically significant increase in cell-cell aggregation in PS1 stable transfectants in comparison with controls. Cells overexpressing PS1 mutant showed no increased aggregation. These results indicate that PS1 stimulates cell-cell adhesion. This stimulation seems to be $\mathrm{Ca}^{2+}$-dependent, since $\mathrm{Ca}^{2+}$ removal from the medium results in the loss of intercellular contacts, a finding that is in accordance with the experiments of Baki et al. [40]. In the presence of $\mathrm{Ca}^{2+}$, PS1-/- cells showed little aggregation in comparison with PS1+/+ cells and cell-cell aggregation was substantially increased in PS1-/- cells by transfection with PS1. Restoration of effective cell-cell adhesion was not achieved by transfection of PS1 mutant lacking exon $9(\Delta \mathrm{E} 9)$. Interestingly, in PS-/- cells, E-cadherin/ $\alpha-, \beta-, \gamma$-catenin interaction is significantly lower than in PS $+/+$ cells, whereas the presence of PS1 increases cadherin/catenin cytoskeletal association. The above data demonstrate that PS1 promotes both E-cadherin interactions with other components of the adhesion complex and its cytoskeletal association, giving new insights into our understanding of the functional role of PS1 in cadherinbased adhesion (fig. 1, left).

\section{Indication for a Role of PS1 in the Trafficking of Cadherins}

In order to explain the mode by which PS1 modulates cell-cell adhesion, it has been suggested that it influences the trafficking of the components of the adhesion to the cell surface $[37,45]$. This explanation is in accordance with previous studies that attribute a role in protein trafficking to PS1 [46, 47]. Consistent with this idea, Uemura et al. [45] noticed that $\mathrm{N}$-cadherin expression is reduced in cells expressing mutant PS1 (D385A) and the protein has an abnormally higher molecular weight compared to that in control cell lines. This finding indicates an impaired maturation and trafficking of $\mathrm{N}$-cadherin. Newly synthesized $\mathrm{N}$-cadherin is proteolytically processed into the mature form before its transport to the plasma membrane [48]. Provided that the N-cadherin-dependent cellcell adhesion requires the recruitment of an intracellular $\mathrm{N}$-cadherin pool to the plasma membrane [49], it is easy to appreciate that proper trafficking of $\mathrm{N}$-cadherin is of crucial importance for the efficient function of the synaptic adhesions assuring the interneuronal communication and the processing of the information. It is tempting to speculate that PS1 FAD mutations may interfere with the trafficking of N-cadherin, resulting in the impairment of the synaptic activity of neurons [45]. This theory is of great importance if one considers that a pathological feature of $\mathrm{AD}$ is extensive synaptic loss, which is strongly correlated with the degree of dementia [50].
186

Neurodegenerative Dis 2004;1:184-191
Parisiadou/Fassa/Fotinopoulou/Bethani/ Efthimiopoulos 
Fig. 1. PS1 has two distinct roles in relation to CAJs. PS1 is recruited at sites of cell-cell adhesion and stabilizes the E-cadherin/catenin complex (left of the vertical dashed line). Under conditions stimulating apoptosis, Ecadherin is processed in a PS $1 / \gamma$-secretase dependent manner, inducing disassembly of the CAJs. This cleavage produces E-cad/ CTF2, which is released to the cytosol in complex with $\beta$-catenin, a key modulator of the Wnt/Wingless pathway, and might indirectly be implicated in transcriptional regulation (right of the vertical dashed line).

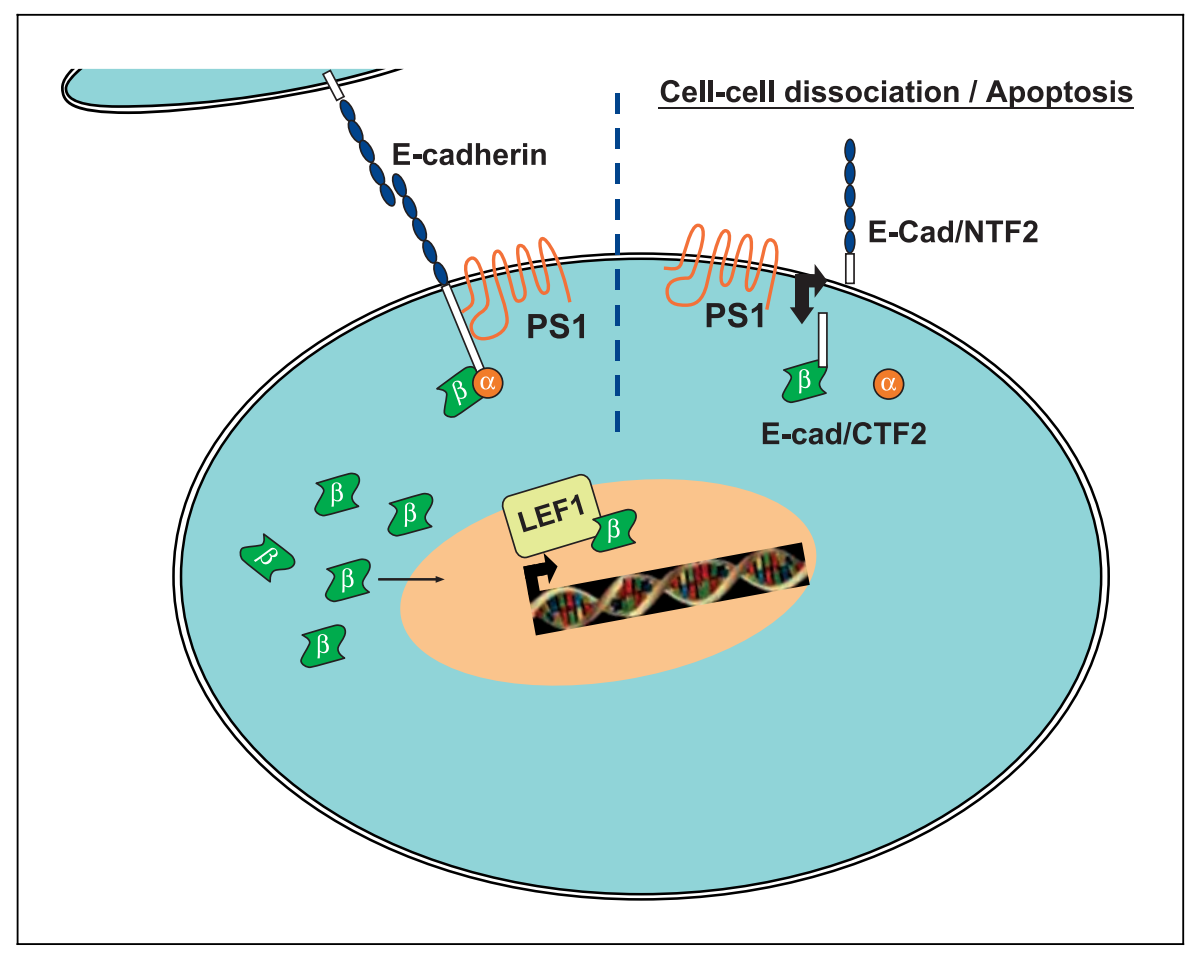

\section{E-Cadherin Is Processed by the PS1/v-Secretase Activity}

Loss of cell-cell contact is one of the numerous morphological changes observed in the absence of $\mathrm{Ca}^{2+}$ or after induction of apoptosis. Under both conditions, the cadherins, who represent the major adhesive system in vertebrates, undergo a conformational change and are processed by specific enzymes, resulting in disassembly of CAJs [51, 52].

Steinhusen et al. [51] have presented data showing that after induction of apoptosis E-cadherin is cleaved by two distinct proteolytic activities, generating three fragments with molecular masses of 24, 29 and $84 \mathrm{kD}$. More specifically, they suggested that E-cadherin is cleaved by a metalloprotease resulting in the shedding of extracellular domain from the cell surface and the production of a transmembrane carboxyl-terminal fragment, which is further processed to a smaller fragment $(24 \mathrm{kD})$. Production of this peptide is abolished by a specific caspase-3 inhibitor, indicating the involvement of caspase-3. Marambaud et al. [35] extended the study of Steinhusen et al. [51] and they reported a novel PS $1 / \gamma$-secretase activity implicated in the proteolysis of E-cadherin after induction of apoptosis. Staurosporine treatment of A431 cells yielded three CTFs of E-cadherin (E-cad/CTF1, E-cad/CTF2, and
E-cad/CTF3). The E-cad/CTF1 is produced by the action of a matrix metalloproteinase after Pro700 residue at the extracellular domain of E-cadherin (fig. 1, right). Moreover, this MMP-mediated cleavage of the protein results in the release of an extracellular N-terminal fragment. E-cad/CTF1 is processed to the E-cad/CTF2 in a PS1/ $\gamma$-secretase-dependent manner, since the specific $\gamma$-secretase inhibitor L-685,458 completely blocked its production (fig. 1, right). Sequencing of the amino terminus of E-cad/CTF2 revealed that the cleavage takes place between amino acids 731-732 at the interface of the transmembrane and cytoplasmic domains of E-cadherin and corresponds to the $\varepsilon$-cleavage by PS1/ $\gamma$-secretase. Multiple lines of experimental evidence suggest a potent role of $\mathrm{PS} 1 / \gamma$ secretase cleavage of E-cadherin in the disassembly of CAJs. Ionomycin induces a decrease of cytoskeletal associated (ionic detergent insoluble) E-cadherin, $\alpha$ - and $\beta$-catenin, and a subsequent increase of soluble cytosolic E-cad/CTF2, $\alpha$ - and $\beta$-catenin. Treatment with the $\gamma$ secretase inhibitor blocks the production of soluble cytosolic E-cad/CTF2 and inhibits the solubilization of the catenins. This data indicates that the PS $1 / \gamma$-secretasedependent $\varepsilon$-cleavage that generates E-cad/CTF2 results in the dissociation of E-cadherin from the cytoskeleton and its release to the cytosol in complex with $\beta$-catenin, addressing its role in the disassembly of cadherin junc- 
Fig. 2. $\mathrm{PS} 1 / \gamma$-secretase cleavage of $\mathrm{N}$-cadherin is involved in CREB-mediated gene expression. PS1 interacts with $\mathrm{N}$-cadherin and is localized at synaptic sites [37] (left of the vertical dashed line). Membrane depolarization or NMDA receptor agonists induce PS1/ $\gamma$-secretase cleavage of N-cadherin, leading to the production of $\mathrm{N}-\mathrm{cad} /$ CTF2. N-cad/CTF2 represses CREB-mediated transcription, possibly by binding to CBP, and promoting its degradation [59] (right of the vertical dashed line). PS1 FAD mutations do not produce N-cad/CTF2, so there is no repression of CREB-dependent gene activation.

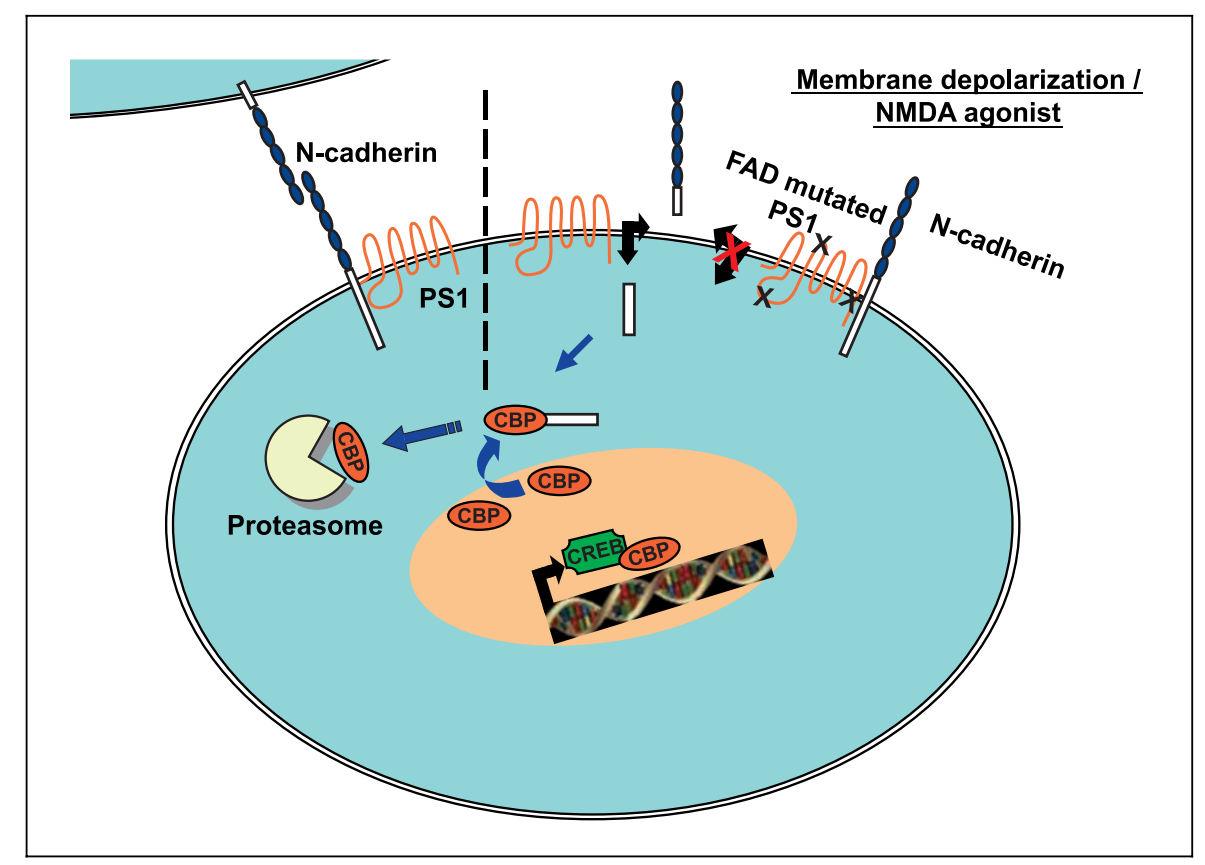

tions. It is interesting that PS1 possesses two distinct roles in relation with the functional integrity and stability of the adhesion: at sites of cell-cell contact it stabilizes the cadherin/catenin adhesion complex and under conditions that facilitate E-cadherin catabolism (apoptosis, $\mathrm{Ca}^{2+} \mathrm{im}-$ balance), it regulates disassembly of the junctions (fig. 1). In addition, the PS $1 / \gamma$-secretase-dependent release of the complex E-cad/CTF2 with $\beta$-catenin possibly links the action of PS1 with transcription regulation that can take place after the release of $\beta$-catenin. Under certain conditions $\beta$-catenin can be released from its complex with E$\mathrm{cad} / \mathrm{CTF} 2$, translocate to the nucleus and induce transcription in complex with the lymphocyte enhancer-binding factor 1 (LEF-1)-responsive transcription factor [53]. These observations are in accordance with a study which indicates that $\beta$-catenin binding to the cadherin cytoplasmic tail either in the membrane or in the nucleus can inhibit $\beta$-catenin degradation and efficiently block its transactivation capacity [54].

\section{Regulated Intramembrane Proteolysis, PS and Transcriptional Activation}

Cell-surface receptors transmit their signals via ion influxes or complicated protein kinase signaling cascades. A number of receptors, however, are processed by a rather different signaling mechanism called regulated intramem- brane proteolysis 'RIP' [55]. A number of studies have described RIP as two-step proteolysis receptors that release their intracellular fragments to the cytosol. These fragments alone or in association with other proteins can potentially translocate to the nucleus and regulate gene activation. An increasing piece of evidence suggests that the release of the intracellular fragments from cell surface receptors is PS $1 / \gamma$-secretase dependent and takes place at the interface of their transmembrane and cytoplasmic domains ( $\varepsilon$-cleavage) [55]. Indeed, Notch, APP [56], receptor tyrosine kinase ErbB4 [57], cell adhesion molecules CD44 [58], E [35]- and N-cadherin [59] and lowdensity-lipoprotein-receptor-related protein (LRP) [60] have been reported to release their intracellular soluble fragment in a PS1/ $\gamma$-secretase-dependent manner.

One of the substrates undergoing PS1/ $\gamma$-secretasedependent intramembrane proteolysis is N-cadherin. PS1 forms complexes with $\mathrm{N}$-cadherin in neurons catalyzing the production of an $\mathrm{N}$-cadherin $\mathrm{C}$-terminal fragment (N-cad/CTF2) [59] after induction by membrane depolarization or stimulation of the NMDA receptor (fig. 2).

A number of different experimental procedures suggest that the N-cad/CTF2 interacts with CBP (CREB binding protein) and promotes its proteasomal degradation. CBP binds to CREB and regulates the initiation of the CREBmediating transcription of target genes [61]. CREB is involved in a number of normal cellular events and diseases including human neurodegenerative disorders [61] 
and among the genes that are expressed under its control are those implicated in the plasticity of the nervous system [62]. Since CBP is mainly localized in the nucleus, it has not been determined whether N-cad/CTF2 is able to 'recruit' the nuclear CBP pool to the cytosol or whether it interacts with newly synthesized CBP. The interaction of $\mathrm{N}$-cad/CTF2 with CBP results in suppressed CREBdependent gene activation, as reported by the specific reduction in the expression of the gene c-fos, which is controlled by the CREB/CBP activity. The above findings imply a model of PS-mediated transcriptional regulation (fig. 2). A remarkable observation is that a number of different PS1 mutants associated withAD do not promote $\mathrm{N}-\mathrm{cad} / \mathrm{CTF} 2$ production and fail to suppress CRE-mediating transactivation and c-fos expression.

Therefore, a key role for PS1 as a repressor of transcriptional activity is proposed, and could be related to a number of recent studies that point out the idea that PS1/ $\gamma$-secretase-dependent intramembrane proteolysis of receptors is a more generic mechanism of cell surface-tonucleus signal transduction $[55,63]$.

\section{AD and Transcriptional Dysregulation}

The 'amyloid hypothesis' has been accepted for more than a decade as the main theory according to which the involvement of $A \beta$ peptide, a proteolytic fragment of APP, is the main causative agent of the AD progression $[64,65]$. However, a number of studies are inconsistent with this theory and argue that the amyloid hypothesis does not adequately explain the correlation between amyloid deposition and the pathophysiology of the disease $[66,67]$. Some of the most important arguments are the presence of brain amyloid deposition in nondemented elderly people [68] and the study of transgenic mice models, where mice expressing mutated forms of human APP and/or PS show only some of the neuropathological and behavioral abnormalities characteristic of AD [69-72]. However, the mice did not present all the symptoms of the disease and they cannot be regarded as having the $\mathrm{AD}$ phenotype. In addition, there is the fact that almost 95\% of people having AD without APP and PS1 mutations cannot be accounted for by the amyloid hypothesis. It is, therefore, easy to appreciate that $\mathrm{AD}$ is a multifactorial neurodegenerative disorder and further studies are required in order to elucidate the causes of the neuronal function impairment of $\mathrm{AD}$ patients.

Thus, the involvement of PS1 in transcriptional regulation as described earlier enhances our view on the contribution of PS1 mutations to AD, suggesting that these mutations are responsible for neuronal dysfunction by impairing the activity of specific genes, and not only by interfering with $\beta$-amyloid production [73].

\section{Acknowledgments}

We thank Dr. Robakis for critically reading the manuscript and making stimulating comments. This research was supported by the European Union under the programme 'Quality of Life and Management of Living Resources', Key Action 3 'The Cell Factory', Contract No. QLK3-CT-2001-02362.

\section{References}

1 Selkoe DJ: Alzheimer's disease: Genes, proteins, and therapy. Pharmacol Rev 2001;81 741-766.

2 Hardy J: The Alzheimer family of diseases: Many etiologies, one pathogenesis? Proc Nat Acad Sci USA 1997;94:2095-2097.

$\checkmark 3$ Cai XD, Golde TE, Younkin SG: Release of excess amyloid beta protein from a mutant amyloid beta protein precursor. Science 1993; 259:514-516.

4 Suzuki N, Cheung T, Cai X-D, Okada A, Otvos L, Eckman C Jr, Golde TE, Younkin SG: An increased percentage of long amyloid-beta protein secreted by familial amyloid-beta protein precursor (APP717) mutants. Science 1994; 264:1336-1340. $\checkmark 5$ Scheuner D, Eckman C, Jensen M, Song X, Citron M, Suzuki N, Bird TD, Hardy J, Hutton M, Kukull W, Larson E, Levy-Lahad E, Viitanen M, Peskind E, Poorkaj P, Schellenberg G, Tanzi R, Wasco W, Lannfelt L, Delkoe DJ, Younkin S: Secreted amyloid $\beta$-protein similar to that in the senile plaques of Alzheimer's disease is increased in vivo by the presenilin 1 and 2 and APP mutations linked to familial Alzheimer's disease. Nat Med 1996;2:864-870.

6 Borchelt DR, Thinakaran G, Eckman CB, Lee MK, Davenport F, Ratovitsky T, Prada C-M, Kim G, Seekins S, Yager D, Slunt HH, Want R, Seeger M, Levey AI, Gandy SE, Copeland NG, Jenkins NA, Price DL, Younkin SG, Sisodia SS: Familial Alzheimer's disease-linked presenilin 1 variants elevate A $\beta 1-42 / 1-40$ ratio in vitro and in vivo. Neuron 1996;17:10051013.
7 Citron M, Oltersdorf T, Haass C, McConlogue L, Hung AY, Seubert P, Vigo-Pelfrey C, Lieberburg I, Selkoe DJ: Mutation of the beta-amyloid precursor protein in familial Alzheimer's disease increases beta-protein production. Nature 1992;360:672-674.

$>8$ Duff K, Eckman C, Zehr C, Yu X, Prada C-M, Perez-Tur J, Hutton M, Buee L, Harigaya Y, Yager D, Morgan D, Gordon MN, Holcomb L, Refolo L, Zenk B, Hardy J, Younkin S: Increased amyloid- $\beta 42(43)$ in brains of mice expressing mutant presenilin 1. Nature 1996;383: 710-713.

9 Robakis NK, Ramakrishna N, Wolfe G, Wisniewski HM: Molecular cloning and characterization of a cDNA encoding the cerebrovascular and the neuritic plaque amyloid peptides. Proc Natl Acad Sci USA 1987;84:4190-4194. 
10 Kang J, Lemaire HG, Unterbeck A, Salbaum JM, Masters CL, Grzeschik KH, Multhaup G, Beyreuther K, Muller-Hill B: The precursor of Alzheimer's disease amyloid A4 protein resembles a cell-surface receptor. Nature 1987;325: 733-736.

11 Selkoe DJ: Cell biology of the amyloid $\beta$-protein precursor and the mechanism of Alzheimer's disease. Annu Rev Cell Biol 1994;10: 373-403.

12 Anderson JP, Esch FS, Keim PS, Sambamurti K, Lieberburg I, Robakis NK: Exact cleavage site of Alzheimer amyloid precursor in neuronal PC-12 cells. Neurosci Lett 1991;128/1: 126-128.

13 Buxbaum JD, Liu KN, Luo Y, Slack JL, Stocking KL, Peschon JJ, Johnson RS, Castner BJ, Cerretti DP, Black RA: Evidence that tumor necrosis factor alpha converting enzyme is involved in regulated alpha-secretase cleavage of the Alzheimer amyloid protein precursor. J Biol Chem 1998;273:27765-27767.

14 Lammich S, Kojro E, Postina R, Gilbert S Pfeiffer R, Jasionowski M, Haass C, Fahrenholz F: Constitutive and regulated alpha-secretase cleavage of Alzheimer's amyloid precursor protein by a disintegrin metalloprotease. Proc Natl Acad Sci USA 1999;96:3922-3927.

-15 Sherrington R, Rogaev EI, Liang Y, Rogaeva EA, Levesque G, Ikeda M, Chi H, Lin C, Li G, Holman K, Tsuda T, Mar L, Foncin J-F, Bruni AC, Montesi MP, Sorbi S, Rainero I, Pinessi L, Nee L, Chumakov I, Pollen D, Brookes A, Sanseau P, Polinsky RJ, Wasco W, Da Silva HAR, Haines JL, Pericak-Vance MA, Tanzi RE, Roses AD, Fraser PE, Rommens JM, St George-Hyslop PH: Cloning of a gene bearing missense mutations in early-onset familial Alzheimer's disease. Nature 1995;375:754-761.

$\checkmark 16$ Li X, Greenwald I: Membrane topology of the C. elegans SEL-12 presenilin. Neuron 1996;17: 1015-1021.

17 Doan A, Thinakaran G, Borchelt DR, Slunt HH, Ratovitsky T, Podlisny M, Selkoe DJ, Seeger M, Gandy SE, Price DL, Sisodia SS: Protein topology of presenilin 1. Neuron 1996; 17:1023-1030.

18 Podlisny MB, Citron M, Amarante P, Sherrington R, Xia W, Zhang J, Diehl T, Levesque G, Fraser P, Haass C, Koo EHM, Seubert P, St George-Hyslop P, Teplow DB, Selkoe DJ: Presenilin proteins undergo heterogeneous endoproteolysis between Thr291 and Ala299 and occur as stable $\mathrm{N}$ - and C-terminal fragments in normal and Alzheimer brain tissue. Neurobiol Dis 1997;3:325-337.

19 Capell A, Grunberg J, Pesold B, Diehlmann A, Citron M, Nixon R, Beyreuther K, Selkoe DJ, Haass C: The proteolytic fragments of the Alzheimer's disease-associated presenilin-1 form heterodimers and occur as a 100-150-kDa molecular mass complex. J Biol Chem 1998;273: 3205-3211.

-20 Wolfe MS, Xia W, Ostaszewski BL, Diehl TS, Kimberly WT, Selkoe DJ: Two transmembrane aspartates in presenilin-1 required for presenilin endoproteolysis and -secretase activity. Nature 1999;398:513-517.
21 Li Y-M, Xu M, Lai M-T: Photoactivated $\gamma$ secretase inhibitors directed to the active site covalently label presenilin 1. Nature 2000;405: 689-694.

22 Esler WP, Kimberly WT, Ostaszewski BL, Diehl TS, Moore CL, Tsai J-Y, Rahmati T, Xia W, Selkoe DJ, Wolfe MS: Transition-state analogue inhibitors of $\gamma$-secretase bind directly to presenilin-1. Nat Cell Biol 2000;2:428-434.

23 Seiffert D, Bradley JD, Rominger CM, Rominger DH, Yang F, Meredith JE Jr, Wang Q, Roach AH, Thompson LA, Spitz SM, Higaki JN, Prakash SR, Combs AP, Copeland RA, Arneric SP, Hartig PR, Robertson DW, Cordell B, Stern AM, Olson RE, Zaczek R: Presenilin-1 and -2 are molecular targets for gamma-secretase inhibitors. J Biol Chem 2000;275:3408634091 .

$24 \mathrm{Yu}$ G, Nishimura M, Arawaka S, Levitan D, Zhang L, Tandon A, Song YQ, Rogaeva E, Chen F, Kawarai T, Supala A, Levesque L, Yu H, Yang DS, Holmes E, Milman P, Liang Y, Zhang DM, Xu DH, Sato C, Rogaev E, Smith M, Janus C, Zhang Y, Aebersold R, Farrer LS, Sorbi S, Bruni A, Fraser P, St George-Hyslop P: Nicastrin modulates presenilin-mediated notch/glp-1 signal transduction and APP processing. Nature 2000;407:48-54.

25 Goutte C, Tsunozaki M, Hale VA, Priess JR: APH-1 is a multipass membrane protein essential for the Notch signaling pathway in Caenorhabditis elegans embryos. Proc Natl Acad Sci USA 2002;99:775-779.

26 Francis R, McGrath G, Zhang J, Ruddy DA, Sym M, Apfeld J, Nicoll M, Maxwell M, Hai B, Ellis MC, Parks AL, Xu W, Li J, Gurney M, Myers RL, Himes CS, Hiebsch R, Ruble C, Nye JS, Curtis D: Aph-1 and pen-2 are required for notch pathway signaling, $\gamma$-secretase cleavage of APP, and presenilin protein accumulation. Dev Cell 2002;3:85-97.

27 Kimberly WT, LaVoie MJ, Ostaszewski BL, Ye W, Wolfe MS, Selkoe DJ: $\gamma$-Secretase is a membrane protein complex comprised of presenilin, nicastrin, aph-1 and pen-2. Proc Natl Acad Sci USA 2003;100:6382-6387.

28 Takasugi N, Tomita T, Hayashi I, Tsuruoka M, Niimura M, Takahashi Y, Thinakaran G, Iwatsubo T: The role of presenilin cofactors in the $\gamma$-secretase complex. Nature 2003;422:438441.

$29 \mathrm{Hu}$ Y, Ye Y, Fortini ME: Nicastrin is required for $\gamma$-secretase cleavage of the Drosophila notch receptor. Dev Cell 2002;2:69-78.

30 Edbauer D, Winkler E, Regula JT, Pesold B, Steiner H, Haass C: Reconstitution of gammasecretase activity. Nat Cell Biol 2003;5:486488.

31 Haass C, Schlossmacher M, Hung AY, VigoPelfrey C, Mellon A, Ostaszewski B, Lieberburg I, Koo EH, Schenk D, Teplow D, Selkoe $\mathrm{DJ}$ : Amyloid $\beta$-peptide is produced by cultured cells during normal metabolism. Nature 1992; 359:322-325.

32 Haass C, Hung AY, Schlossmacher MG, Teplow DB, Selkoe DJ: $\beta$-Amyloid peptide and a 3-kDa fragment are derived by distinct cellular mechanisms. J Biol Chem 1993;268:30213024.
$33 \mathrm{Gu}$ Y, Misonou H, Sato T, Dohmae N, Takio $\mathrm{K}$, Ihara $\mathrm{Y}$ : Distinct intramembrane cleavage of the beta-amyloid precursor protein family resembling gamma-secretase-like cleavage of Notch. J Biol Chem 2001;276:35235-35238.

34 Sastre M, Steiner H, Fuchs K, Capell A, Multhaup G, Condron MM, Teplow DB, Haass C: Presenilin-dependent gamma-secretase processing of beta-amyloid precursor protein at a site corresponding to the $\mathrm{S} 3$ cleavage of Notch. EMBO Rep 2001;2:835-841.

35 Marambaud P, Shioi J, Serban G, Georgakopoulos A, Sarner S, Nagy V, Baki L, Wen P, Efthimiopoulos S, Shao Z, Wisniewski T, Robakis NK: A presenilin-1/gamma-secretase cleavage releases the E-cadherin intracellular domain and regulates disassembly of adherens junctions. EMBO J 2002;21:1948-1956.

36 Weidemann A, Eggert S, Reinhard FB, Vogel M, Paliga K, Baier G, Masters CL, Beyreuther $\mathrm{K}$, Evin G: A novel epsilon-cleavage within the transmembrane domain of the Alzheimer amyloid precursor protein demonstrates homology with Notch processing. Biochemistry 2002;41: 2825-2835

37 Georgakopoulos A, Marambaud P, Efthimiopoulos S, Shioi J, Cui W, Li HC, Schutte M Gordon R, Holstein GR, Martinelli G, Mehta $\mathrm{P}$, Friedrich VL Jr, Robakis NK: Presenilin-1 forms complexes with the cadherin/catenin cell-cell adhesion system and is recruited to intercellular and synaptic contacts. Mol Cell 1999;4:893-902.

38 Cook DG, Sung JC, Golde TE, Felsenstein KM, Wojczyk BS, Tanzi RE, Trojanowski JQ, Lee VM, Doms RW: Expression and analysis of presenilin 1 in a human neuronal system localization in cell bodies and dendrites. Proc Natl Acad Sci USA 1996;93:9223-9228.

39 De Strooper B, Beullens M, Contreras B, Levesque L, Craessaerts K, Cordell B, Moechars D, Bollen M, Fraser P, George-Hyslop PS, Van Leuven F: Phosphorylation, subcellular localization, and membrane orientation of the Alzheimer's disease-associated presenilins. J Biol Chem 1997;272:3590-3598.

40 Baki L, Marambaud P, Efthimiopoulos S, Georgakopoulos A, Wen P, Cui W, Shioi J, Koo E, Ozawa M, Friedrich VL Jr, Robakis NK: Presenilin-1 binds cytoplasmic epithelial cadherin, inhibits cadherin/p120 association, and regulates stability and function of the cadherin/catenin adhesion complex. Proc Natl Acad Sci USA 2001;98:2381-2386.

41 Anastasiadis PZ, Reynolds PB: The p120 catenin family: Complex roles in adhesion, signaling and cancer. J Cell Sci 2000;113:13191334.

42 Ireton RC, Davis MA, van Hengel J, Mariner DJ, Barnes K, Thoreson MA, Anastasiadis PZ, Matrisian L, Bundy LM, Sealy L, Gilbert B, van Roy F, Reynolds AB: A novel role for p120 catenin in E-cadherin function. $\mathrm{J}$ Cell Biol 2002; 159:465-476.

43 Davis MA, Ireton RC, Reynolds AB: A core function for p120-catenin in cadherin turnover. J Cell Biol 2003;163:525-534. 
-44 Xiao K, Allison DF, Buckley KM, Kottke M, Vincent PA, Faundez V, Kowalczyk AP: Cellular levels of p120-catenin function as a set point for cadherin expression levels in microvascular endothelial cells. J Cell Biol 2003;163:535545.

-45 Uemura K, Kitagawa N, Kohno R, Kuzuya A, Kageyama T, Chonabayashi K, Shibasaki H, Shimohama S: Presenilin 1 is involved in maturation and trafficking of $\mathrm{N}$-cadherin to the plasma membrane. J Neurosci Res 2003;74: 184-191.

-46 Efthimiopoulos S, Floor E, Georgakopoulos A, Shioi J, Cui W, Yasothornsrikul S, Hook VYH, Wisniewski T, Buee L, Robakis NK: Enrichment of presenilin 1 peptides in neuronal large dense-core and somatodendritic clathrincoated vesicles. J Neurochem 1998;71:23652372.

47 Naruse S, Thinakaran G, Luo J-J, Kusiak JW, Tomita T, Iwatsubo T, Qian X, Ginty DD, Price DL, Borchelt DR: Effects of PS1 deficiency on membrane protein trafficking in neurons. Neuron 1998;21:1213-1221.

-48 Wahl JK 3rd, Kim YJ, Cullen JM, Johnson KR, Wheelock MJ: N-cadherin/catenin complexes assemble prior to cleavage of the proregion and transport to the plasma membrane. $\mathrm{J}$ Biol Chem 2003;278:17269-17276.

49 Mary S, Charrasse S, Meriane M, Comunale F, Travo P, Blangy A, Gauthier-Rouviere C: Biogenesis of N-cadherin-dependent cell-cell contacts in living fibroblasts is a microtubuledependent kinesin-driven mechanism. Mol Biol Cell 2002;13/1:285-301.

50 Terry RD: The pathogenesis of Alzheimer disease: An alternative to the amyloid hypothesis. J Neuropathol Exp Neurol 1996;55:10231025.

-51 Steinhusen U, Weiske J, Badock V, Tauber R, Bommert K, Huber O: Cleavage and shedding of E-cadherin after induction of apoptosis. $\mathrm{J}$ Biol Chem 2001;276:4972-4980.

$\checkmark 52$ Vallorosi CJ, Day KC, Zhao X, Rashid MG, Rubin MA, Johnson KR, Wheelock J, Day ML: Truncation of the $\beta$-catenin binding domain of E-cadherin precedes epithelial apoptosis during prostate and mammary involution. $\mathrm{J}$ Biol Chem 2000;275:3328-3334.
53 Behrens J, von Kries JP, Kuhl M, Bruhn L, Wedlich D, Grosschedl R, Birchmeier W: Functional interaction of $\beta$-catenin with the transcription factor LEF-1 of special interest. Nature 1996;382:638-642.

54 Sadot E, Simcha I, Shtutman M, Ben-Ze'ev Avri, Geiger B: Inhibition of $\beta$-catenin-mediated transactivation by cadherin derivatives. Cell Biol 1998;95:15339-15344.

55 Fortini ME: Gamma-secretase-mediated proteolysis in cell-surface-receptor signalling. Nat Rev Mol Cell Biol 2002;3:673-684.

56 Chen F, Gu Y, Hasegawa H, Ruan X, Arawaka S, Fraser P, Westaway D, Mount H, St GeorgeHyslop P: Presenilin 1 mutations activate gamma 42-secretase but reciprocally inhibit epsilon-secretase cleavage of amyloid precursor protein (APP) and S3-cleavage of Notch. J Biol Chem 2002;277:36521-36526.

57 Lee HJ, Jung KM, Huang YZ, Bennett LB, Lee JS, Mei L, Kim TW: Presenilin-dependent gamma-secretase-like intramembrane cleavage of ErbB4. J Biol Chem 2002;277:6318-6323.

58 Okamoto I, Kawano Y, Murakami D, Sasayama T, Araki N, Miki T, Wong AJ, Saya H: Proteolytic release of CD44 intracellular domain and its role in the CD44 signaling pathway. $\mathrm{J}$ Cell Biol 2001;155:755-762.

59 Marambaud P, Wen PH, Dutt A, Shioi J, Takashima A, Siman R, Robakis NK: A CBP binding transcriptional repressor produced by the PS1/epsilon-cleavage of N-cadherin is inhibited by PS1 FAD mutations. Cell 2003;114:635645.

60 May P, Reddy YK, Herz J: Proteolytic processing of low density lipoprotein receptor-related protein mediates regulated release of its intracellular domain. J Biol Chem 2002;277:1873618743.

61 Goodman RH, Smolik S: CBP/p300 in cell growth, transformation, and development. Genes Dev 2000;14:1553-1577.

62 Lonze BE, Ginty DD: Function and regulation of CREB family transcription factors in the nervous system. Neuron 2002;35:605-623.
63 Ebinu JO, Yankner BA: A RIP tide in neuronal signal transduction. Neuron 2002;34:499-502.

64 Glenner GG, Wong CW: Amyloidogenesis in Alzheimer's disease and Down's syndrome; in Banbury Report 27: Molecular Neuropathology of Aging. Cold Spring Harbor, Cold Spring Harbor Press, 1997, pp 53-265.

65 Robakis NK, Pangalos MN: Involvement of amyloid as a central step in the development of Alzheimer's disease. Neurobiol Aging 1994;15: S127-129.

66 Neve RL, Robakis NK: Alzheimer's disease: A re-examination of the amyloid hypothesis. Trends Neurosci 1998;21/1:15-19.

67 Robakis N: An Alzheimer's disease hypothesis based on transcriptional dysregulation. Amyloid 2003;10/2:80-85.

68 Hyman BT, Trojanowski JQ: Consensus recommendations for the postmortem diagnosis of Alzheimer disease from the National Institute on Aging and the Reagan Institute Working Group on diagnostic criteria for the neuropathological assessment of Alzheimer disease. J Neuropathol Exp Neurol 1997;56:1095-1097.

69 Sturchler-Pierrat C, Abramowski D, Duke M, Wiederhold KH, Mistl C, Rothacher S: Two amyloid precursor protein transgenic mouse models with Alzheimer disease-like pathology. Proc Natl Acad Sci USA 1997;94:1328713292.

70 Masliah E, Sisk A, Mallory M, Games D: Neurofibrillary pathology in transgenic mice overexpressing V717F $\beta$-amyloid precursor protein. J Neuropathol Exp Neurol 2001;60:357-368.

71 Phinney AL, Deller T, Stalder M, Calhoun ME, Frotscher M, Sommer B, Staufenbiel M, Jucker M: Cerebral amyloid induces aberrant axonal sprouting and ectopic terminal formation in amyloid precursor protein transgenic mice. $\mathrm{J}$ Neurosci 1999; 19:8552-8559.

72 Chui DH, Tanahashi H, Ozawa K, Ikeda S, Checler F, Ueda O, Suzuki P, Araki W, Inoue H, Shirotani K, Talahashi K, Gallyas F, Tabira $\mathrm{T}$ : Transgenic mice with Alzheimer presenilin 1 mutations show accelerated neurodegeneration without amyloid plaque formation. Nat Med 1991;5:560-564.

73 Fortini ME: Neurobiology: Double trouble for neurons. Nature 2003;425:565-566. 